\title{
Implementing regional marine policies at the eastern mediterranean, through an ecosystem based marine spatial planning
}

\begin{abstract}
Future uses of maritime space at the Eastern Mediterranean such as blue energy, gas and oil exploration, extraction of raw materials, together with permanent activities such as maritime shipping, fishing, aquaculture, tourism, indicate the involvement of different levels of authorities, various stakeholders, public and economic operators for an integrated management approach. Up to date, there hasn't been any marine planning implemented at the area, despite the enhanced human activities and the utilization of maritime space. The commitments to the 2014/89/EU Directive and the Integrated Maritime Policy, establish a definite framework for the implementation of an ecosystem-based management marine spatial planning, specifying more efficient regional marine policies.
\end{abstract}

Volume 2 Issue I - 2015

\section{Eleni Hatziyanni}

Environment and Spatial Planning, Greece

Correspondence: Eleni Hatziyanni, Director of Environment and Spatial Planning, Region of Crete, M Mousourou 15, 7I201, Heraklion, Crete, Greece, Tel 30 28I34I0II8,

Email elhatziyanni@crete.gov.gr

Received: December 15, 2014 | Published: February 16, 2015

Keywords: Marine Spatial Planning, Mediterranean, Regional Marine Policies

\section{Introduction}

As demands for maritime space have significantly been increased the last decades, management of marine areas has been turned out into complicated and sensitive procedures, by involving different levels of authorities and various stakeholders, including the public. Future uses of maritime space such as blue energy, gas and oil exploration, extraction of raw materials, together with permanent activities such as shipping, fishing, aquaculture, tourism, indicate the involvement of economic operators and the necessity of an integrated management approach, succeeding to an effective marine spatial planning. ${ }^{1}$ Consultation of authorities, stakeholders and public during the preparation of any plans, should result to an adequate marine spatial planning and regarding the particularities of marine regions, existing national policies and legislation, and by securing the compliance with relative regulations. ${ }^{2}$

At the Mediterranean, Malta Environment \& Planning Authority (MEPA), $2007^{3}$ report a few years ago, has overviewed the state of marine spatial planning in the Mediterranean countries, addressing the marine uses at the Mediterranean, without yet a consistent and integrated approach for maritime planning, namely because the focus had primarily been mainly in controlling development on land. Since Adriplan Project financed by the EU Commission (DG Mare), and INTERREG Greece-Cyprus "Interregional cooperation for the marine spatial planning development" aim to improve the ongoing process to develop Marine Spatial Planning in the Adriatic Ionian Macro region by using the best knowledge available and evaluating potential conflicts and synergies among marine and maritime uses focusing Northern/Southern Adriatic Sea, Northern Ionian Sea and Aegean Sea. Up to date, there hasn't been neither prepared nor established any maritime planning, despite the enhanced human activities in the Eastern Mediterranean marine area and the utilization of maritime space.

Blue Growth as the overarching objective of the maritime dimension of Europe 2020 together with Maritime Strategy address challenges and opportunities at the sea, focused on blue energy together with development of technologies for sustainable seafood production. On the other hand, the South East Europe 2020 Strategy follows the objective of governance for growth, including compliance with EU regulations whereas actions related to maritime governance and services can contribute to effective e public services including common standards in fisheries, aquaculture and coastal zone management. The latter is in respect to the objectives of the pillars of EU Strategy of Adriatic Ionian Macro region (endorsed by EU leaders on 24/10/2014), applied to an important surface marine area at the Eastern Mediterranean, concerning eight countries (4 EU countries: Croatia, Greece, Italy, Slovenia, 3 candidates countries: Albania, Montenegro, Serbia and 1 potential candidate country: Bosnia and Herzegovina).

The commitments to the 2014/89/EU Directive of the European Parliament and of the Council, and the Integrated Maritime Policy of the Union applied to marine waters of the EU Member States, establish a definite framework for the implementation of maritime spatial planning. Land-sea interactions have been taken into account, together with the economic and social aspects, by requiring an ecosystem approach, for the congruous coexistence of activities and maritime uses, through environmental aspect for sustainable development.

The increasing maritime traffic congestion at the Mediterranean and the cross-road located marine area, the fast growing factor of tourism in the islands, but also the increased human use of the marine and coastal space are combined with a cultural and natural heritage and biodiversity, in respect to the extremely oligotrophic marine environment of the eastern basin, indicate a marine ecosystembased management, as a new generation of multi sectoral spatial planning tool, for implementing sustainable marine policies. In such a dimension, marine spatial planning implementation at the Eastern Mediterranean should successfully regulate human uses of marine space, by protecting marine environment and delivering the marine ecosystem services and societal benefit, and by analyzing and managing the ecosystem from a holistic approach, specifying more efficient regional marine policies.

\section{Acknowledgments}

None. 


\section{Conflicts of interest}

None.

\section{References}

1. Elliott M. The 10-tenets for integrated, successful and sustainable marine management. Mar Pollut Bull. 2013;74(1):1-5.
2. Olsen E, Fluharty D, Hoel AH, et al. Integration at the round table: marine spatial planning in multi-stakeholder settings. PLoS One. 2014;9(10):e109964.

3. Malta Environment \& Planning Authority MEPA. An overview of the state of marine spatial planning in the Mediterranean countries. 2007. 